Georgia State University

ScholarWorks @ Georgia State University

2014

\title{
Civic Paternalism in Political Policymaking: The Justification for No-Vote Stadium Subsidies
}

Timothy Kellison

Georgia State University, tkellison@gsu.edu

Michael Mondello

University of South Florida, mmondello@usf.edu

Follow this and additional works at: https://scholarworks.gsu.edu/kin_health_facpub

Part of the Kinesiology Commons

\section{Recommended Citation}

Kellison, Timothy and Mondello, Michael, "Civic Paternalism in Political Policymaking: The Justification for No-Vote Stadium Subsidies" (2014). Kinesiology Faculty Publications. 54.

doi: https://doi.org/10.1123/jsm.2012-0210

This Article is brought to you for free and open access by the Department of Kinesiology and Health at ScholarWorks @ Georgia State University. It has been accepted for inclusion in Kinesiology Faculty Publications by an authorized administrator of ScholarWorks @ Georgia State University. For more information, please contact scholarworks@gsu.edu. 


\begin{abstract}
Direct democracy practices such as initiatives and referenda are increasingly ignored or circumvented by political leaders who allocate subsidies toward new professional sport stadium developments. In a democracy, such a means of governing may be problematic if the outcome is unreflective of the public will. The existing literature makes several theoretical connections for this line of political decision-making, including urban growth machines and trustee-delegate representation. In this paper, these concepts are integrated with empirical evidence to support the conceptualization of civic paternalism, a term that provides partial description of the political decision-making process. Civic paternalists justify their decisions by arguing that a city's continued vibrancy and growth optimize community benefit while remaining acutely aware of their decisions' political consequences. We illustrate the concept of civic paternalism by drawing from interviews with political leaders associated with one of the most recent cases of the no-vote subsidy.
\end{abstract}

Keywords: public policy, political science, public subsidies, public sport facilities, sport finance, stadium construction 
Civic Paternalism in Political Policymaking: The Public Justification For No-vote Stadium Subsidies

The literature related to stadium financing and voting outcomes has ranged widely (cf. Brown \& Paul, 2002; Buist \& Mason, 2010; deMause \& Cagan, 2008; Hyatt, 2007; Mondello \& Anderson, 2004; Spirou, 2011; Trumpbour, 2006). Still, nearly all of this diverse literature shares the broad project of identifying the factors contributing to the passage or defeat of stadium-financing ballot issues. Implicitly assumed in this research agenda is that the tools of direct democracy—namely, the initiative and the referendum — are regularly used to determine the extent of public support in stadium projects. Indeed, some scholars have characterized direct democracy and stadium finance as having a very close relationship. Coates and Humphreys (2003) noted that stadium referenda "occur frequently" (p. 1), while Dehring, Depken, and Ward (2008) claimed that the decision to subsidize a stadium "is often finalized at the ballot box" (p. 156).

Prior to the mid-2000s, those claims could be made with little disagreement. Brown and Paul (2002) identified 40 stadium referenda spanning 1984 to 2000, and Mondello and Anderson (2004) observed 26 referenda across 19 cities from 1990 to 2000 . However, as discussed in this paper, a growing trend in stadium finance is the prevalence of the no-vote subsidy, in which elected officials and public servants allocate public funds toward the construction or renovation of a professional sport stadium without public consent (i.e., without the introduction of an initiative or referendum). This practice is not entirely new — as Eisinger (2000) noted, "Referenda on whether to commit public funds to the construction of big entertainment amenities are not in fact the norm" (p. 323) — but it is becoming an increasingly ubiquitous practice. Since 
2005, 24 stadium projects representing nearly $90 \%$ of all stadium development have been allocated over $\$ 8.5$ billion of public funds without any form of voter approval.

In instances of no-vote subsidies, it is unclear whether the common interests of ordinary citizens are reflected in the policies of the local government. Those operating in a system in which the actions of elected officials are incongruent with the wishes of their voting constituencies are compelling, and it is important to consider the reasoning of elected officials who make such controversial decisions. The purpose of this study is to consider why decisionmakers elect to allocate municipal funds toward professional sport stadium projects without the endorsement of the public collective.

To achieve this aim, we employ an interdisciplinary approach designed to appreciate the diverse academic disciplines in which this topic is relevant. First, we follow Santo's (2005) counsel to utilize a case-study approach when exploring the nuances of individual stadiumfinance issues; additionally, we highlight one of the most recent cases of the no-vote subsidy in professional sport. Next, we summarize the relevant literature related to urban growth machine theory and models of political representation. We then integrate this literature into our conceptualization of civic paternalism as the public justification of policymakers for no-vote subsidies. Finally, we present empirical evidence that support our contention and discuss the theoretical and practical implications of the study.

\section{Democracy and the Rise of the No-vote Subsidy in Columbus, Ohio}

In a representative democracy, delegates are selected to act on behalf of their constituents. In this form of democracy, elected officials are encouraged, and expected, to consider the best interests of all of their citizens (Magleby, 1984). Comparatively, direct democracy provides citizens with the opportunity to participate directly in the legislative process. 
Referenda and initiatives are forms of direct democracy because they allow citizens to vote directly on legislation, even in democracies that are otherwise structured on the representative model. Historically, the pursuit of public money for a sport stadium culminated in a vote by local citizens. As Fort (1997) noted, the primary reason for democratizing the stadium-finance issue was simply to adhere to legal requirements related to changing tax protocols or issuing bonds. When an initiative or referendum is not legally required, public officials nevertheless often included it on a ballot in order to defer the decision to local citizens. In addition, Fort argued, the purpose of the democratic process (i.e., voting) is to ensure that the desires of the majority are realized in policymaking. However, as discussed previously and shown in Table 1, public votes on stadium-finance issues are no longer routine: only five public votes (four of which expressed approval) have occurred in cities subsidizing stadium projects from 2005 to 2012.

Insert Table 1 about here

One of the most recent no-vote subsidies was awarded in Columbus, Ohio. In May 1997, voters there rejected a referendum that would have increased the local sales tax over three years, thereby generating an expected $\$ 203.5$ million which, along with investments from private corporations and contributions from the state of Ohio, was to have been used for a development in downtown Columbus anchored by a 21,000-seat multipurpose arena. However, voters defeated the referendum 56.3\% to 43.7\% (Brown \& Paul, 2002; Curry, Schwirian, \& Woldoff, 2004). Columbus voters had previously rejected similar referenda in 1978 (65\% no), 1981 (79\% no), 1986 (53\% no), and 1987 (56\% no; “Key Dates,” 2011). Just one month after the 1997 vote, plans for arena development resurfaced. Private investors agreed to finance the $\$ 150$ million 
required for the arena, eliminating the need for local subsidies. Ground was broken for Nationwide Arena in May 1998, and the National Hockey League's Columbus Blue Jackets began play there in 2000. The sequence of events in Columbus was a clear-though cursoryexample of the efficacy of the will of the people: individuals were provided the opportunity to vote in matters affecting them; public sentiment was reflected in the policymaking outcome; and this view was acknowledged and adhered to during subsequent arena planning (i.e., Nationwide Arena was built through private investment).

The Nationwide Arena resolution turned out not to be the final decision on the funding of this facility, however. In late 2011 and early 2012, Columbus city council members and Franklin County commissioners approved plans for the city and county to purchase Nationwide Arena using $\$ 42.5$ million of tax revenues generated from a newly constructed casino in the city. The plan for the public acquisition of Nationwide Arena (hereafter referred to as the PANA Plan) is especially compelling considering the historic reluctance of Columbus voters to support such initiatives. No referendum vote was taken on this most recent use of public funds.

According to the PANA Plan, Nationwide Arena would be purchased by the Franklin County Convention Facilities Authority (FCCFA, representing the city and county) for $\$ 42.5$ million. When accounting for arena upgrades and projected operating (e.g., utilities, maintenance and janitorial service, game day personnel; Greenberg, 2000) and capital expenditures (e.g., scoreboard upgrades; Bell, 2012), the total cost of the transaction would be $\$ 53.3$ million. To pay for the arena, the FCCFA would receive a $\$ 43.3$-million loan from Nationwide Realty Investors and a \$10-million loan from the Ohio Department of Development, \$5 million of which would be forgiven if the Blue Jackets met "certain roster and payroll requirements" (City of Columbus, 2011, p. 10). The city's and county's payment obligations 
would be repaid using casino-generated tax revenue. In 2009, Ohio voters had passed a constitutional amendment that authorized the development of casinos - one each in the state's four most populous cities: Cincinnati, Cleveland, Columbus, and Toledo. Under the amendment, the state stood to collect $33 \%$ of the casino's gross revenues, to be distributed among Ohio's 88 counties (O. Const. amend. to art. XV, § 6, repealed 2010). On October 3, 2011, the Columbus city council approved the purchase of Nationwide Arena using this revenue; on December 19, Franklin County's three commissioners gave unanimous approval (Trimble, 2011). The purchase closed on March 28, 2012 (Caruso, 2012).

It seems counterintuitive for elected officials to enact policies that are unreflective of popular sentiment, given both their job description as representatives of the public and their dependence on public support to keep their jobs in future elections. As has been argued in the past, circumventing the directly democratic process increases the likelihood of securing public financing for a stadium initiative, but at the potential expense of organizational legitimacy (Fort, 1997; Kellison \& Mondello, 2012). In the Columbus case, therefore, we might have expected that knowledge of previously rejected referenda would persuade policymakers to initiate a referendum for the current electorate in order to assess whether Columbus residents had changed their minds regarding public subsidization of an arena. Contrary to that expectation, policymakers implemented a plan without seeking public approval. The present study addresses how decision-makers reconciled their circumvention of a referendum with the aforementioned characteristics of their positions. In consideration of the policymakers' perspective in this case, we use the section below to integrate previous literature on political decision-making to argue that government actors justify the potential incompatibility of their decisions with public opinion by rationalizing that the policies serve the best interests of the local collective. 


\section{Civic Paternalism}

In the case of the Columbus Blue Jackets and Nationwide Arena, community resentment was expected by policymakers, as illustrated by Columbus city auditor Hugh Dorrian in a 2011 interview in the Columbus Dispatch. He attempted to deflect the anticipated public criticism by arguing that the PANA Plan was significantly different from plans voters had rejected in the past. He noted that all referenda previously rejected by Franklin County voters included regressive sales-tax increases; because the latest subsidization plan differed insofar as its funding apparatus was casino-generated revenues, local residents would not be directly affected, assuming they chose not to patronize the casino (Caruso, 2011).

Still, the decision to pursue public financing for Nationwide Arena despite anticipated taxpayer disapproval suggests that decision-makers in Columbus believe they possess greater knowledge of civic issues than do their constituents. This belief exemplifies civic paternalism, a political decision-making strategy grounded in a trustee form of representation and the belief that a city's economic growth will optimally benefit the local collective. Sometimes, acts motivated by civic paternalism may contradict community sentiment. As discussed below, civically paternalistic leaders justify such decisions by pointing to their belief that a given policy serves the best interests of the entire community - even if community members do not realize that is so.

\section{Theoretical Foundations}

Urban growth machines. Literature on the urban growth machine helps to explain the political fascination with the professional sport stadium. As Molotch (1976) argued, "the political and economic essence of virtually any given locality, in the present American context, is growth" (pp. 309-310). In his view, the underlying desire for growth and expansion unites local decision-makers who otherwise have little in common. Generally, developmental policies 
designed to elicit positive economic benefits (as opposed to allocational or redistributive policies) are well received by the voting public (Peterson, 1981). For that reason, city leaders tend to support professional sports and stadiums "as instruments of economic development and affirmations of the importance of their city or metropolitan area" (Danielson, 1997, p. 15).

As noted in previous research, several broad factors are influential in stadium-finance decision-making. Delaney and Eckstein (2003) investigated the influence of local growth coalitions - alliances between a city's business elite, who often have major stakes in the securing of public funds for a facility—on stadium-financing outcomes. They compared cities with strong growth coalitions (e.g., Pittsburgh, Cleveland, and Cincinnati) with those with weak growth coalitions (e.g., Denver, Phoenix) and concluded that the strength of the growth coalition was a significant influencer of stadium-finance outcomes. Similarly, Paul and Brown (2001) found that unified support from a region's elite class increased the probability a stadium issue would pass. More recently, Delaney and Eckstein (2007) explored the influence of growth coalitions in Cincinnati and Minneapolis by conducting interviews with over 70 individuals, many of whom were high-level executives and business leaders, involved in each city's facility debates. They offered several possible explanations for the pursuit of stadium initiatives by growth coalitions and policymakers, including executive recruitment and to assuage declining urban populations.

The political power of the growth coalition is rooted in the theory of collective action (Euchner, 1993). This theory holds that it is easier for a city's business elite to organize than it is for smaller groups with diverse interests to do so. Because the business elites share the objective of a prosperous local economy, they often ally and invest in projects designed to obtain that common goal. On the other hand, anti-subsidy groups may be opposed to public stadium funding for numerous reasons (e.g., fiscal conservatism, opportunity costs); therefore, they may 
not form a unified group. As a result, economic issues often take precedence over social issues in a city's political landscape. The political power of these groups means that policymakers seeking reelection benefit from endorsing projects that benefit the coalition.

Public choice theory and models of democratic representation. According to urban growth machine theory, elected officials are motivated to legislate in ways that will maximize their political welfare and minimize their political risk. Previous analyses of stadium-financing cases have resulted in similar claims. For example, Santo (2010) drew from public choice theory, the economic theory that individuals are motivated by their own self-interests, to contend that "politicians are not driven by an altruistic desire to serve the public interest but rather by a desire to promote their own self-interest" (p. 86).

In the political science literature, several generic models of representation have been proposed to explain whether elected officials rely on their own expertise or consult their constituents. In a trustee form of representation, elected officials have "an electoral incentive to use [their] expertise and pursue policies that [they believe] promote the general welfare" (Fox \& Shotts, 2009, p. 1225). Conversely, elected officials adhering to the delegate form of representation are politically motivated to enact policies that reflect popular opinion, regardless of their personal expertise. A third type of representative, the politico, will alternate between the previous two forms depending on the degree to which an issue has polarized the public. Each of the three representative forms is similar because all assume elected officials will adopt the model with the greatest electoral incentive.

Democracy and paternalism. Ben-Ishai (2012) noted, "individual autonomy-the capacity to determine one's own ends or life plans - is a central value in liberal democracies" (p. 151). Therefore, some question whether a paternalistic state can rightly be called a democracy. 
Dworkin (1971) defined paternalism as “the interference with a person's liberty of action justified by reasons referring exclusively to the welfare, good, happiness, needs, interests or values of the person being coerced" (p. 108). Paternalism is modeled on the traditional fatherchild relationship, in which the father holds absolute authority over his children; his decisions, though sometimes unpopular, are always made in the best interests of his family (i.e., "father knows best"; Jackman, 1994). However, despite the apparent benevolence in the father-child relationship, there is a wide range of opinion regarding the value of paternalism (Pellegrini \& Scandura, 2008).

The concept of civic paternalism emerges from a Rousseauian interpretation of the role an individual plays in shaping the larger will of the people as a collective. In The Social Contract, Rousseau contended that the general will — and the laws emerging from that general will — reflect the best interests of society. Taking for granted that the general will (what he refers to as the Sovereign) is always right and just, Rousseau acknowledged that an individual's selfinterests may be trumped by the general will:

As soon as this multitude is so united in one body, it is impossible to offend against one of the members without attacking the body, and still more to offend against the body without the members resenting it. Duty and interest therefore equally oblige the two contracting parties to give each other help; and the same men should seek to combine, in their double capacity, all the advantages dependent upon that capacity.

Again, the Sovereign, being formed wholly of the individuals who compose it, neither has nor can have any interest contrary to theirs; and consequently the sovereign power need give no guarantee to its subjects, because it is impossible for the body to wish 
to hurt all its members. ... The Sovereign, merely by virtue of what it is, is always what it should be. (1762/2007, I.VII)

Rousseau argued that once a collection of individuals develops into a society, they form a new organism complete with its own unique fate. Therefore, society's general will may be distinct from the will of its individual members; in such cases Rousseau held that the general will prevails.

According to the paternalist philosophy, the popular opinion of a community may be worthy of consideration, but ultimately, only those with decision-making power (sovereigns) know which decisions will best serve the collective's interests. An understanding of policymakers as civic paternalists thus differs from the models described above in that it sees policymakers as more interested in the effects of their decisions on the entire community than on either their allies in the business elite or their future electoral success. However, we will argue that these models are potentially complementary, as civic paternalists may understand all three of these outcomes to be intrinsically related: what is best for the business elite is best for the entire community; recognizing that, the community will be likely to reelect these policymakers. Moreover, we will argue that a policymaker might endorse a no-vote subsidy in particular because evidence suggests that these actions — even when unpopular among the citizenry — may be politically inconsequential.

\section{Civic Paternalism in Columbus Arena Policy}

As illustrated in Figure 1, there are two unpopular outcomes of a sport stadium proposal that may be explained by civic paternalism: (a) voters reject a public-funding proposition but decision-makers nevertheless direct subsidies to the facility, as has been the case in cities like Pittsburgh and Charlotte (City Council of the City of Charlotte, 2002; Mecham, 2006); or (b) 
legislators allow public investiture in a facility initiative without seeking the approval of local citizens, as has occurred in 24 facilities subsidized without voter consent since 2005.

Insert Figure 1 about here

Civic leaders faced with deciding whether to allocate public funding toward a professional sporting venue must consider the impact on a number of constituencies. In Columbus, voters have traditionally rejected all proposals designed to subsidize local sports facilities. After city council members and county commissioners agreed to purchase Nationwide Arena from a private insurance company (thereby "saving" the Columbus Blue Jackets, a

privately owned sports organization; Caruso, 2011), questions were raised concerning the lack of citizen input. Such a decision could be justified by the logic of civic paternalism, the view by political policymakers that they know better than their constituents how to achieve the common good.

\section{Methods}

Although the cities and stadiums listed in Table 1 share a common outcome, each case's no-vote subsidy resulted from a series of unique events. Therefore, it is important to consider context when forming an opinion about the appropriateness of a stadium's financing. In recognition of the influence of context, Santo (2005) advocated for an increase in case-study analyses in order to draw more precise conclusions:

Case studies... which focus on one or a few cities... are able to inherently account for the context in which sports facilities are built. This focus is important because... a facility's ability to impact its local economy is tied to its context. This point can be overlooked in the analysis and reporting of cross-section time-series research. In addition, when the 
results of numerous empirical analyses are synthesized into broad conclusions, the nuances of individual findings are eroded. (p. 190)

Following the direction of Santo's recommendation, standardized open-ended interviews were conducted in person with seven individuals connected to the Columbus PANA Plan. Each individual was either a member of the working group who developed the plan, a Franklin County commissioner, or a Columbus city councilmember. In sum, 15 individuals made up the membership of these three groups. Members of the working group (though not necessarily participants in this study) included: Columbus mayor Michael B. Coleman; his chief of staff, Michael D. Reese; city council president Andrew J. Ginther; Franklin County commissioner John O’Grady; city auditor Hugh J. Dorrian; county administrator Don L. Brown; special counsel to the city John C. Rosenberger; and executive director of the county convention facilities authority, William C. Jennison. Of the seven participants, three were elected officials who had direct votes on the PANA Plan, while the remaining four were members of the working group. The interviews were conducted in each individual's office or conference area. Interviews were recorded and transcribed verbatim. Interviews ranged in length from $18 \mathrm{~min} 5 \mathrm{sec}$ to $1 \mathrm{hr}$ $14 \mathrm{~min} 44 \mathrm{sec}$; the average length was $37 \mathrm{~min} 41 \mathrm{sec}$. Data were analyzed in the tripartite sequence suggested by Strauss and Corbin (1990). The interview responses are being reported largely in the form of verbatims to support interpretive validity (Johnson \& Christensen, 2008).

Furthermore, between-method triangulation was utilized to improve the internal trustworthiness of the interview responses. In addition to the interview testimony, official and internal documents (e.g., meeting minutes, city ordinance proposals, county resolutions) and press coverage of the PANA Plan were analyzed. Following the guidelines of Fico, Lacy, and Riffe (2008), the researchers grouped "expressions" into categories through the development of a 
multi-stage coding protocol. In the first stage, primary expressions were categorized according to a number of recurring themes throughout the literature (e.g., urban growth machine, democratic representation). Following the identification of the primary themes, each document was analyzed and assigned, when applicable, to the aforementioned themes. When necessary, articles were coded into multiple themes. In cases where the anonymity of the public official can be protected, external support of her or his statement is provided.

In the results presented below, each interviewee has been assigned a pseudonym. Individuals who had direct votes in the PANA Plan (i.e., city councilmembers, county commissioners) are preceded with the title "Elected Official." These individuals represent the policymakers of interest. Non-voting members - all of whom were members of the city's arenafinancing working group — are assigned the title "Executive." These individuals were actively involved in the development of the PANA Plan and worked alongside the policymakers. Therefore, their personal accounts provide further insight on the decision-making processes of the policymakers. Finally, to protect the anonymity of the interviewees, consistent gender pronouns have been assigned to both groups: members of the Elected Officials group are referred to as male, while members of the Executive group are referred to as female.

This qualitative research design was utilized for discovery, description, and theory development (Rudd \& Johnson, 2010). The purpose of the interviews was to gain insight about the projected benefits of, perceived opposition to, and level of public support toward the Columbus PANA Plan, from the perspective of the policymakers. This pseudo-grounded theory approach takes into account the importance of fit, understanding, generality, and control (Glaser \& Strauss, 1967). More generally, the interviewers' responses inform the civic-paternalism 
conceptualization. As shown below, two primary themes emerged from our analyses, both of which describe what policymakers think about when deliberating about no-vote subsidies.

\section{Results and Discussion}

\section{“Good policy and good politics": Trustee support of the growth machine.}

Policymakers sometimes make decisions that may be unpopular among a portion of their many constituents, who include ordinary citizens, business leaders, and special interest groups. With respect to the Columbus arena-financing case, in interviews policymakers expressed support for the PANA Plan based on a number of reasons, all of which had to do with maintaining or bolstering the urban growth machine. These reasons included supporting "a vital Arena District," averting a "shot to the ego" of a prospering city, and protecting “ 10,000 jobs." However, policymakers were quick to connect the city's economic growth with the quality of life of ordinary citizens. As argued by Executive Nicklaus, the defense-of-jobs issue was particularly important considering the troublesome economic climate since the late 2000s: "I think people understood, especially in a time of a recession, that fighting for every job and retaining every job you can is good policy and good politics." Highlighting the central arguments for the Arena District, Executive Owens argued that action was necessary in order to keep the Blue Jackets financially solvent and sustain the district's attractiveness:

I think just the economic development [inaudible] jobs is at the top of the list, and right before that, it seems to me, would be the community image with-our competition with our peer municipalities.... This has to do with the citing of future jobs. It has to do with the tourism. It has to do with—where the young intelligentsia is choosing to live.... Would you want to live someplace that's a little boring or do you want to live someplace 
where they've got some professional sports? Where there's some buzz.... It gives them cache with that demographic.

Otherwise, the team would likely have relocated, thereby leaving the arena without a central tenant, which would cause economic distress throughout the district. The threat of relocation, though not introduced by Blue Jackets' management, had appeared in press coverage (e.g., Brown, 2011; Caruso, 2011; Hart, 2011), and other policymakers echoed the importance of avoiding relocation throughout the interviews.

A key assumption among civically paternalistic actors is that, while they themselves are aware of how a decision impacts an entire community, private individuals lack the same breadth of knowledge and are instead motivated by self-interests. This assumption is epitomized in the following response by Elected Official Hayes:

I think that when I look at things like this vote, I look at the fact that I'm looking at a whole big picture. So, in that respect, I'm thinking about a much bigger picture than an individual voter might be thinking about. I don't know. I think about a lot of what I do as: is this in the best interests of the community? I'll listen to perspectives; I always am willing to listen to perspectives and I read the letters that come in, and in the end, I will vote based on what $I$ believe makes the most sense. And looking at all the pieces and parts of everything else going on, I don't get pressured by outside influences, so I don't feel that pressure. There was pressure out there to support this, but I didn't really feel that pressure.

Furthermore, those involved in the PANA Plan reinforced the belief that the majority of citizens were either uninterested or uninformed when it came to the specifics of the deal. This position was supported by Kraft and Furlong (2007), who argued, “The attentive public can be 
distinguished from the general public. The attentive public, typically less than 10 percent of the public, includes those who are apt to take an interest in a particular problem or policy" (p. 52). While Elected Official Hayes confessed, “I don’t think most residents care,” Executive Owens stated that although public awareness of the Blue Jackets' grim financial situation was strong, understanding of how the PANA Plan worked was much weaker:

...It's a pretty complicated deal, and let's face it, for most people, the most complicated thing they've ever done is buy a house. And so, all of this is just meaningless. They sort of look at the net result, which is, "All right, they stay in town. All right, I understand that creates some jobs. Yeah, that's sort of important to our image, I get that. Nobody's going to send me a new tax bill." For most people: "I'm not in the safety net, so that's not material to me." I mean, it's one of those things that people just use fuzzy logic on and decide, "Oh, yeah. OK. Next. What's the next issue?"

Her contention that ordinary citizens lacked both awareness and understanding of the plan's particulars typifies the trustee orientation of the civically paternalistic leader. According to Owens, the ordinary citizen grasped only the broad implications of the deal. Though not stated by Owens, this excerpt suggests that the representative form of democracy was most appropriate in the Columbus arena-financing case because an uninformed and uninvolved citizenry is not ideal in a direct democracy.

Even though they defended the no-vote subsidy, policymakers in Columbus speculated about whether the community would have supported the plan had it gone to a public vote. Predictions varied, but no policymaker voiced concern that the issue would have been defeated in a landslide. As one interviewee contended, a key factor in the hypothetical outcome of a vote is whether the electorate would have valued the arena's discounted cost. Additionally, Executive 
Harley deferred to the city council and county commission's support of the deal as an expression of the will of the people:

The elected officials are sort of my gauge as to where the public is because the mayor had to approve it, seven city councilmembers had to approve it, and three county commissioners... and they run for election, they know the voters, and in working with them, I think we came up with a package that they felt would meet voter muster if it had to go to that. They're pretty sophisticated when it comes to understanding the electorate and I think they felt that, on balance, this was a good proposal.

This response is indicative of Harley's assumption that policymakers were acting democratically by making decisions representing the desires of their electorate.

Interestingly, Elected Official Griffin emphatically predicted voters would have passed the arena issue. The reason, he explained, is that the local government would have created a public campaign to highlight the benefits of the Arena District:

If you had to hold - if we put this to a public vote this past fall and said, "Fund it or don't fund it," even in the environment we're in now, it would have passed. I still believe it would have passed... and the reason it would have passed is Nationwide and the Blue Jackets and the county commissioners and the mayor and everybody else-we would have put on a public campaign. They would have paid for TV commercials; we'd have all been in them and we would've talk about the impact that the arena had-arena district has - on Columbus. They would have showed pictures of it. You could have-it wouldn't have even been close. I wouldn't even think it would have been close. Now, if it was a straight-up vote - ask me right now — then maybe it would have been closer. But 
not after 30 to 60 days of TV commercials and an explanation of what it is. No. It wouldn't have even have been close. We would have won that vote in a heartbeat. Griffin argued that a highly publicized campaign would have informed the public about the reasons why subsidizing the arena was important to the city. In his view, this information was already known by elected officials, but members of the community needed educating in order to come to the same realizations. From Griffin's perspective, after the message got out to the public, the imperative of approving the PANA Plan would be seen by all.

As the above responses indicate, policymakers involved in the Columbus PANA Plan overwhelmingly believed the public majority lacked comprehension of the plan's details. Certainly, they did not argue that the public was incapable of such understanding (indeed, the suggested strategy of a pro-subsidy publicity campaign indicates a belief that the public could be educated on the topic), but rather, that the public was simply apathetic to the case. Additionally, the policymakers expressed faith that a review by Franklin County voters would have had a favorable outcome; however, their answers to this hypothetical question (with the exception of the Griffin's testimony) commonly exuded a lack of certainty.

The promise of urban growth was an important part of the Franklin County policymakers' rationalization for the PANA Plan. In some cases, they acknowledged that some citizens might oppose the funding apparatus or any professional sports subsidy. Additionally, they conceded that some voters would prefer that casino revenues be directed toward improving schools, infrastructure, and civil services. In response to these concerns, interviewees suggested investment in growth would lead to additional resources for other programs and projects. This idea is reflective of a civically paternalistic ideology; while cognizant of opposing views (and the potential political consequences of enacting policies that contradicted popular views), civically 
paternalistic leaders rely on their personal expertise to legislate in ways that secure their cities' continued growth. This growth, in their view, will best serve the public will.

\section{"I'll worry about that when the time comes": The political consequences of the no-}

vote subsidy. When an act of civic paternalism might not be supported by the public, policymakers must come to terms with the possible political consequences of their decisions. Biglaiser and Mezzetti (1997) found that politicians who were confident they would be reelected were more likely to begin new projects around election season, while those who were less certain of their electability were less likely to engage in new ventures. Elected officials are considerate of the political consequences of their decisions. In Executive Nicklaus' words:

Yeah, I think there's tension there. Any elected official—whether you're term limited or not; or whether you have two-year terms, four-year terms; whether you're a mayor, councilmember, country commissioner, [representative], whatever-I think anyone has in their mind, "How is this going to impact me the next time I run?" or, "How am I going to be viewed, whether I'm running or not?' You know, I think that that's natural.

One policymaker commented specifically on the political risk taken by some freshman councilmembers. When asked if any of the elected officials were susceptible to losing a council seat from their adoption of the PANA Plan, Elected Official Griffin responded, "Absolutely." As he elaborated, it was unclear how the public would respond to the city council and county commission's adoption of the arena-financing plan:

...There was definitely some concern that the two new appointed city councilmembersvery good folks - they're turning out to be great councilmembers - but had never been on a ballot before - running for their first time and voting for this thing that, you knowthere really hadn't been any polls... The council president had done polls internally, but 
there hadn't been any public polls, so there was no real knowledge or understanding of what really the public thought.

This statement provides insight into the policymakers' gauge of public support. Griffin noted that no member of the city council or county commission was aware of the public's opinion toward the plan. This reflects the trustee orientation of policymakers, who believed their expertise on the issue, coupled with the perceived lack of knowledge of citizens, made analysis of public opinion unnecessary.

There was at least some trepidation that the arena-financing plan could inflame some voters. In the passage below, Elected Official Griffin spoke at length to the initial reluctance of some political leaders to develop an arena-financing plan during election season:

...There were at different times when there were some political leaders in this town that wanted to just say, "Let's get through an issue"; "let's get through an election"; "let's get through...," you know, those type of things. But, they never said, "I don't want to talk about this" or "let's forget that idea." They might say, "Let's forget it for six months," but they wouldn't say, "Let's forget it."

And there were times when I think people were...even like, “Aw, I don't want to deal with that right now." But nobody that I know of...said, "I will not support that." Not one. And it took - well it took heavy lifting. The mayor had to lift, and then it took seven votes at city council, and three votes [from the commissioners] - well, four votes at city council and two votes [from the county commission] — but again, it passed unanimously, both places. So, I mean, I think that's...an important point to make. It's not like this was politically contentious. It was just - there were times and things going on-environmental issues that were happening throughout this conversation that at 
different times said, "You know what? Let's get this taken care of before we deal with that." "Let's get past this election before we deal with that."

The apprehension of Franklin County policymakers to engage in negotiations about the Arena District suggests that at least some leaders were concerned about how their actions would impact their favorability among their constituents.

Although the lack of a collective opposition may have soothed the consciences of some policymakers, the voices of a few opponents were still memorable. Elected Official Griffin recounted a specific incident in which an acquaintance offered his unfavorable opinion of the deal:

I have had people come up to me of all walks of life and say, "What? Why would you do that?" I even had an attorney here in town —-very well respected—we know him...who cornered me and got in my face at a Christmas party and...pretty much pinned me up against the table and railed on me about this and I just—-Hey, look. We're not ever going to agree on this, so just drop it. It's just where we are."

As Executive Owens remarked, some opponents lacked compelling arguments and were instead fueled by indiscriminant antagonism:

...To tell you this - when I got asked to do this, I'd been around for a long time and not been vilified or anything like that. I'm getting along OK. So anyway, I agreed to do this and I logged onto Dispatch or something. I don't know what it was. I found this place where people can leave anonymous comments. Oh, it was brutal. Oh my god, it was breathtaking. In fact, after a few minutes, I thought, I can't read this. This is just going to screw me up. I'm not going read this. Every once in awhile, somebody would say, “Oh, she's a good person." There were those who would just cut me to ribbons. So, I'll 
tell you, those people are out there and they're not even not necessarily principled, they're just caught up in anger at everything.

These events, while uncommon, provided evidence to decision-makers that some community members were displeased with the PANA Plan.

From a political perspective, elected officials were faced with choosing between two philosophical points of view, as explained by Executive Owens:

...We know policymakers have to exist in the middle, and...I think the middle is the place that you need to be. ...I've watched over the years, these decisions that come on about are we going to deploy resources to strengthen the safety net and expand the safety net — whatever — or are we going to do things that create jobs, that keep people out of the safety net? That's the toughest decision that really comes on, and there are passions on both sides of this thing. You understand. It's inflamed by the passions of the electorate and all of those are visited on these poor policymakers that have to make these tough decisions.

The above statement illustrates the tensions felt by policymakers. Within the context of welfare issues, policymakers are aware of the opposing arguments within their individual constituencies. In the stadium-financing context, some may favor investing in ways that protect individuals from economic crises (e.g., by investing in economic engines such as stadiums in order to promote the health of the urban growth machine), while others may support sending direct aid to those most in need (e.g., by investing in welfare programs and homeless shelters). While the majority opinion would certainly be worthy of consideration, an act of civic paternalism would be based primarily on what the decision-maker believed would serve the best interests of the entire community. 
Though policymakers engaging in acts of civic paternalism must be willing to face the political consequences of their actions when their decisions contradict public sentiment, negative consequences do not always result. In some cases, voters may not penalize an official in the next election; elected officials are equally aware of this potential outcome. Electoral slack refers to situations in which "governments believe that they are in a strong enough position to absorb the electoral consequences of unpopular decisions" (Pierson, 1996, p. 176). While the possibility for political fallout existed for some policymakers (specifically, the Columbus city council's freshman members), Elected Official Griffin expressed confidence that even an unpopular decision would not have harmed his reelection bid:

You know, there are things that we do that you know it's a tough vote. Believe me. About-I'd say one out of 15 or 20 votes that you take, you're [upsetting someone]. Maybe not even that - it might even be even less than that - maybe one out of every 10 votes that you make, you're [upsetting someone]. But—and I think I'm in a little bit of a different situation for a lot of reasons, political and other-...I'm pretty good at the political stuff, so I put myself in a pretty good political position so that I don't have to worry that - at least in terms of reelection.

Elected Official Hayes similarly felt protected by his electoral slack: "I don't think it was that big of a risk."

While the policymakers indicated the perceived low risk associated with supporting the PANA Plan, they also acknowledged that sometimes their unpopular decisions could lead to negative consequences. The possibility of losing their positions in government weighed heavily on the elected policymakers. In the end, the importance of doing what they considered "right" 
overruled concerns about their political futures, as reflected in the decision-making processes of two elected officials. As stated by Elected Official Hayes:

I think elected officeholders take risks all the time. If you're going to lead, you're going to lead. Sometimes, we make decisions that people don't like. Sometimes, we make decisions people like. So, is there a risk? Of course, there's a risk that when we're up for reelection, somebody may bring it up. I don't know how this will be, but in the end-I can't speak for anybody else — but I have to say, for me, I do what I think is right at the time I do it. And I felt that this was the best, right thing to do and I don't have any problem at all when it's time for me to run for reelection in [2014] standing up for that decision.

Similarly, Elected Official Griffin commented:

I think about it when I'm flying home from Washington or when I'm up late at night that some of the things that I've decided on might make it difficult for me to run for a different office someday. I'll worry about that when the time comes, but I'm not going to not do the right thing because of that.

In the end, policymakers in Columbus had to come to terms with the possibility that their decisions could curtail their future political endeavors. In acts of civic paternalism, this realization is necessary in order for policymakers to lead without the endorsement of the electorate.

Since these interviews were conducted, a grassroots organization known as the Columbus Coalition for Responsive Government initiated an amendment that would block public payments to Nationwide Arena beginning in 2016. This amendment, which would be subject to a public vote, would effectively repeal the arena-financing deal. Should this citizen-led initiative prove 
successful, Franklin County policymakers might reappraise the political consequences of supporting the PANA Plan. Charges that the PANA Plan is unconstitutional have also emerged, but these criticisms have focused on fiscal provisions in the Ohio Constitution rather than the decision-making process (Ebersole, 2013).

\section{Concluding Remarks}

In this study, we contended that civic paternalism enabled policymakers to justify the Columbus PANA Plan, a decision that may or may not have been representative of the community collective. Some may question the validity or honesty of the testimony provided by the PANA Plan policymakers; others outside of the decision-making process might give very different accounts of how and why the process unfolded as it did. Still, the results of the interviews are valuable as a public record of the PANA Plan policymakers' justification for the no-vote subsidy. The city councilmembers and county commissioners interviewed for this study all attempted to reconcile the seeming inconsistency between their positions as representatives and their failure to seek public opinion through a vote by arguing that the PANA Plan was best for the entire community, and would be even if voters who disagreed later voted elected officials out of office. The validity of an interview participant's testimony is always subject to scrutiny; in this study, readers must assess the trustworthiness of the statements given. In some ways, this methodological concern and the electoral process are harmonious, as voters too must decide how to interpret these justifications.

If any single theme emerging from these interviews was to be contested, it would likely be policymakers' claim that they act in ways that benefit the entire community. Given the seldom known but presumably conflicting opinions of citizens, Peterson (1981) defined the general will as an assembly of economic, social, and political interests: 
The interests of cities are neither a summation of individual interests nor the pursuit of optimum size. Instead, policies and programs can be said to be in the interest of cities whenever the policies maintain or enhance the economic position, social prestige, or political power of the city, taken as a whole. (p. 20)

With respect to the PANA Plan, the potential relocation of the Columbus Blue Jackets and loss of Nationwide Arena's primary tenant could have triggered the economic collapse of the Arena District, resulting in massive layoffs, business closings, and the idling of downtown residential activity. Stated differently, the loss of the Blue Jackets could have reversed the significant downtown growth of the past 15 years. This scenario was outlined by multiple PANA Plan policymakers, who argued such a decline would hurt not only those directly impacted through job or revenue loss, but all Franklin County residents. Thus, while some individuals have enjoyed the benefits of a thriving downtown Columbus more than others, all residents are impacted by the urban growth machine.

This study makes several broad contributions to the academic study of both sport and public policy. First, we underscore the prevalence of the no-vote subsidy as an instrument of public-stadium financing. Much of the controversy surrounding the no-vote subsidy comes from the uncertainty about the preference of the public will. Without the evidence of ballot results or poll numbers, individuals can suppose the will of the people at large matches their own preferences. The policymaker favoring the financing plan may speculate the public to be similarly supportive, while the dissenting citizen may argue that the public majority opposes the plan. Civil servants and citizens alike must consider the consequences of policies that are - at least in perception and sometimes in reality_unreflective of the electorate's preferences. 
As we highlight the increasing prevalence of the no-vote subsidy in North American stadium financing, we also acknowledge that there are forms of democratic participation other than a popular vote by local citizens (cf. Held, 2006). For example, town-hall forums and public hearings may provide policymakers with a perspective of the public will when direct democracy is not utilized. In fact, some governments have created statutes aimed at formalizing the citizenparticipation process by requiring community feedback on legislative changes (i.e., New Zealand's Local Government Acts of 1989 and 2002; Sam \& Scherer, 2006). However, previous research has shown that these meetings are often significantly impacted by local policymakers' political agendas. For example, Scherer and Sam (2008) analyzed the content of five public meetings, at which citizens deliberated on the use of public funds for the \$143-million renovation of Carisbrook, a rugby stadium in Dunedin, New Zealand. The researchers observed a number of coercive tactics and politicking in the meetings, and argued that those with a vested interest in the facility (e.g., city officials, the firm commissioned to evaluate the feasibility of the stadium, rugby supporters, wealthy businesspeople) were using their positions to alter the structure of a supposedly democratic process in order to garner more favor for the stadium. Scherer and Sam's work demonstrates that there are democratic alternatives to referendums and initiatives, but these alternatives are not necessarily immune from political influence.

A number of other analyses of the politics behind sport stadium-finance deals have been structured as historical accounts (e.g., Curry et al., 2004; Mason, 2010; Mondello, Schwester, \& Humphreys, 2009; Trumpbour, 2006). Other investigations have centered on the makeup of assorted stakeholders, including voters (Coates \& Humphreys, 2006; Mondello \& Anderson, 2004), political leaders (Carr, 2009), and elite endorsers (Paul \& Brown, 2006). Still others have focused on the alleged benefits and detriments of a publicly financed stadium (e.g., Delaney \& 
Eckstein, 2003; deMause \& Cagan, 2008; Rosentraub, 2010; Zimbalist, 2004). This project encompasses each of these elements in order to provide a critical account of the Columbus PANA Plan.

Second, we conceptualized and defined civic paternalism. Although the literature on political influence in stadium financing has been widespread (e.g., Austrian \& Rosentraub, 1997; Blair \& Swindell, 1997; Rosentraub, 1999; Weiner, 2000), less scholarship has examined the motives and decision-making processes of elected officials from the perspective of individual policymakers. A consideration of this perspective is necessary in order to appreciate the nuances of the decision-making process. In addition, in the case of the Columbus PANA Plan, it is necessary to identify what reasoning, if any, was used by policymakers to legitimate the allocation of public funding to Nationwide Arena without the consent of local citizens. In our interviews, policymakers endorsed subsidizing the arena to save businesses, jobs, and social capital — in other words, to promote the urban growth machine — but insisted that these benefits would be widely shared by the entire community.

Policymakers were aware of the possibility that Franklin County residents might not agree with their support of the PANA Plan. The ideology of civic paternalism is one way in which policymakers are able to temper any personal apprehension caused by the possibility of public disapproval. However, we hesitate to imply that this attitude is always or necessarily dishonest. Our interviews suggest that the attitude of civic paternalism may be not merely a false rhetoric intended to make unpopular decisions more palatable to the public, but may play an actual role in the prospective decision-making process, as policymakers justify their possibly unpopular decisions to themselves. What remains unclear is how local citizens respond to this type of justification. The no-vote subsidy has quickly become the most common form of public 
financing for professional sport facilities in North America. While some researchers have included voter characteristics in their broader analyses of the public-private facility financing debate (Brown \& Paul, 2002; Fort, 1997, 1999; Mondello \& Anderson, 2004), there has not been empirical investigation of the responding opinions and behaviors following no-vote subsidies.

The most immediate outcome of a pro-subsidy policy is that public funds are allocated to a stadium or project; clearly, this outcome is favored by the policymakers behind it. It is unclear if other, more problematic outcomes also emerge from such policies. Future research should focus on identifying these outcomes, which may include reduced favorability toward the policymakers, declining belief in democratic ideals, and increased apathy toward the democratic process. These outcomes represent potential unintended, yet severe, consequences of policies made without voter consent and should be the subject of future empirical study.

Finally, the development of civic paternalism as a policymaker motive pushes the sport management discipline in new directions, including that of interdisciplinary research, which has recently been championed by Doherty (2013). Given the high cost, visibility, and symbolism of professional sports facilities, there is sufficient reason to expand stadium-politics research into the other academies such as public policy, political science, organizational theory, and urban and regional planning. From a scholarly perspective, researchers should continue to engage in interdisciplinary research moving forward. It is difficult to appreciate the nuance and complexity of the no-vote subsidy from any one perspective, and incorporating knowledge from a wide range of disciplines can bring to light new ideas for evaluating the merits of public-stadium financing and the democratic process. The aim of this interdisciplinary approach, then, should be to engage the academy, policymakers, activists, sport managers, and ordinary citizens in such worthwhile debate. 


\section{References}

Austrian, Z., \& Rosentraub, M. S. (1997). Cleveland's gateway to the future. In R. G. Noll \& A. Zimbalist (Eds.), Sports, jobs and taxes: The economic impact of sports teams and stadiums (pp. 355-384). Washington, DC: The Brookings Institution Press.

Bell, J. (2012, April 26). Nationwide Arena getting new scoreboard as part of \$5.5M upgrade. Columbus Business First. Retrieved from http://bizjournals.com/columbus

Ben-Ishai, E. (2012). The new paternalism: An analysis of power, state intervention, and autonomy. Political Research Quarterly, 65, 151-165.

Biglaiser, G., \& Mezzetti, C. (1997). Politicians' decision making with re-election concerns. Journal of Public Economics, 66, 425-447.

Blair, J. P. \& Swindell, D. W. (1997). Sports, politics, and economics: The Cincinnati story. In R. G. Noll \& A. Zimbalist (Eds.), Sports, jobs and taxes: The economic impact of sports teams and stadiums (pp. 282-323). Washington, DC: The Brookings Institution Press.

Brown, P., \& Paul, D. M. (2002). The political scorecard of professional sports facility referendums in the United States, 1984-2000. Journal of Sport and Social Issues, 26, 248-267.

Brown, S. (2011, January 6). Coleman mixed on requests for public help for Blue Jackets. WOSU. Retrieved from http://beta.wosu.org

Buist, E. A., \& Mason, D. S. (2010). Newspaper framing and stadium subsidization. American Behavioral Scientist, 53, 1492-1510.

Carr, P. J. (2009, April). The politics of stadium financing: The price of mayoral support. Paper presented at the Annual Midwest Political Science Association Conference, Chicago, IL. Abstract retrieved from http://www.mpsanet.org 
Caruso, D. (2011, September 15). Saving the Blue Jackets. Columbus Dispatch. Retrieved from http://www.dispatch.com

Caruso, D. (2012, March 30). Taxpayers now own Nationwide Arena. The Columbus Dispatch. Retrieved from http://www.bluejacketsxtra.com

City Council of the City of Charlotte. (2002). Business Meeting Minute Book 118. Retrieved from http://charmeck.org

City of Columbus. (2011b). Nationwide Arena proposal: Finance subcommittee summary report. Retrieved from http://council.columbus.gov

Coates, D., \& Humphreys, B. R. (2003). Voting on stadium and arena subsidies. Unpublished manuscript.

Coates, D., \& Humphreys, B. R. (2006). Proximity benefits and voting on stadium and arena subsidies. Journal of Urban Economics, 59, 285-299.

Curry, T. J., Schwirian, K., \& Woldoff, R. A. (2004). High stakes: Big time sports and downtown redevelopment. Columbus, OH: Ohio State University Press.

Danielson, M. N. (1997). Home team: Professional sports and the American metropolis. Princeton, NJ: Princeton University Press.

Dehring, C. A., Depken, C. A., \& Ward, M. R. (2008). A direct test of the homevoter hypothesis. Journal of Urban Economics, 64, 155-170.

Delaney, K. J., \& Eckstein, R. (2003). Public dollars, private stadiums: The battle over building sports stadiums. Rutgers, NJ: Rutgers University Press.

Delaney, K. J., \& Eckstein, R. (2007). Urban power structures and publicly funded stadiums. Sociological Forum, 22, 331-353. 
deMause, N., \& Cagan, J. (2008). Field of schemes: How the great stadium swindle turns public money into private profit. Lincoln, NE: University of Nebraska Press.

Doherty, A. (2013). “It takes a village:” Interdisciplinary research for sport management. Journal of Sport Madnagement, 27, 1-10.

Dworkin, G. (1971). Paternalism. In R. A. Wasserstrom (Ed.), Morality and the law (pp. 107126), Belmont, CA: Wadsworth.

Ebersole, D. (2013). Democracy in Ohio: Ohio's fiscal constitution and the unconstitutional Nationwide Arena deal. Hastings Constitutional Law Quarterly, 40, 319-392.

Eisinger, P. (2000). The politics of bread and circuses: Building the city for the visitor class. Urban Affairs Review, 35, 316-333.

Euchner, C. C. (1993). Playing the field: Why sports teams move and cities fight to keep them. Baltimore, MD: The Johns Hopkins University Press.

Fico, F. G., Lacy, S., \& Riffe, D. (2008). A content analysis guide for media economics scholars. Journal of Media Economics, 21, 114-130.

Fort, R. (1997). Direct democracy and the stadium mess. In R. G. Noll \& A. Zimbalist (Eds.), Sports, jobs and taxes: The economic impact of sports teams and stadiums (pp. 146-177). Washington, DC: The Brookings Institution Press.

Fort, R. (1999). Stadium votes, market power and politics. The University of Toledo Law Review, $30,419-441$.

Fox, J., \& Shotts, K. W. (2009). Delegates or trustees? A theory of political accountability. Journal of Politics, 71, 1225-1237.

Glaser, B. G., \& Strauss, A. L. (1967). The discovery of grounded research: Strategies for qualitative research. New York, NY: Aldine de Gruyter. 
Greenberg, M. J. (2000). The stadium game (2nd ed.). Milwaukee, WI: Marquette University Press.

Hart, T. (2011, September 15). City officials support Blue Jackets deal. NBC4i. Retrieved from http://www.nbc4i.com

Held, D. (2006). Models of democracy (3rd ed.). Stanford, CA: Stanford University Press.

Hyatt, C. G. (2007). Who do I root for now? The impact of franchise relocation on the loyal fans left behind: A case study of Hartford Whalers fans. Journal of Sport Behavior, 25, 309330.

Jackman, M. R. (1994). The velvet glove: Paternalism and conflict in gender, class, and race relations. Berkeley: University of California Press.

Johnson, R. B., \& Christensen, L. B. (2008). Educational research: Quantitative, qualitative, and mixed approaches (3rd ed.). Thousand Oaks, CA: Sage.

Kellison, T. B., \& Mondello, M. J. (2012). Organisational perception management in sport: The use of corporate pro-environmental behavior for desired facility referenda outcomes. Sport Management Review, 15, 500-512.

Key dates in Nationwide Arena deal. (2011). Columbus Dispatch. Retrieved from http://www.dispatch.com

Kraft, M. E., \& Furlong, S. R. (2007). Public policy: Politics, analysis, and alternatives (2nd ed.). Washington, DC: CQ Press.

Magleby, D. B. (1984). Direct legislation: Voting on ballot propositions in the United States. Baltimore, MD: The Johns Hopkins University Press.

Mason, D. S. (2010). The stadium game in an uncertain environment: A preliminary look at arena discourse in Edmonton, Canada. In S. Butenko, J. Gil-Lafuente, \& P. M. Pardalos 
(Eds.), Optimal strategies in sports economics and management (pp. 97-123). New York, NY: Springer.

Mecham, S. (2006). The house that consensus built: Consensus building in stadium construction. The Urban Lawyer, 38, 1087-1118.

Molotch, H. (1976). The city as a growth machine: Toward a political economy of place. American Journal of Sociology, 82, 309-332.

Mondello, M. J., \& Anderson, P. (2004). Stadiums, arenas, and sports referendums: A comparative analysis of cities involved in the stadium game. International Journal of Sport Management, 5(1), 43-71.

Mondello, M. J., Schwester, R. W., \& Humphreys, B. R. (2009). To build or not to build: Examining the public discourse regarding St. Petersburg's stadium plan. International Journal of Sport Communication, 2, 432-450.

O. Const. amend. to art. XV, $\S 6$ (repealed 2010).

Paul, D. M., \& Brown, C. (2001). Testing the limits of elite influence on public opinion: An examination of sports facility referendums. Political Research Quarterly, 54, 871-888.

Paul, D. M., \& Brown, C. (2006). The dynamics of elite endorsements in professional sports facility referendums. State Politics \& Policy Quarterly, 6, 272-299.

Pellegrini, E. K., \& Scandura, T. A. (2008). Paternalistic leadership: A review and agenda for future research. Journal of Management, 34, 566-593.

Petersen, P. E. (1981). City limits. Chicago, IL: University of Chicago Press.

Pierson, P. (1996). The new politics of the welfare state. World Politics, 48, 143-179.

Rosentraub, M. S. (1999). Major league losers: The real cost of sports and who's paying for it. New York, NY: Basic Books. 
Rosentraub, M. S. (2010). Major league winners: Using sports and cultural centers as tools for economic development. Boca Raton, FL: CRC Press.

Rousseau, J.-J. (2007). The social contract. In G. D. H. Cole (Trans.), The social contract and discourses. LaVergne, TN: BN Publishing. (Original work published 1762)

Rudd, A., \& Johnson, R. B. (2010). A call for more mixed methods in sport management research. Sport Management Review, 13, 14-24.

Sam, M. P., \& Scherer, J. (2006). The steering group as policy advice instrument: A case of “consultocracy" in stadium subsidy deliberations. Policy Sciences, 39, 169-181.

Santo, C. A. (2005). The economic impact of sports stadiums: Recasting the analysis in context. Journal of Urban Affairs, 27, 177-191.

Santo, C. A. (2010). Economic impact of sport stadiums, teams, and events. In C. A. Santo \& G. C. S. Mildner (Eds.), Sport and public policy: Social, political, and economic perspectives (pp. 49-64). Champaign, IL: Human Kinetics.

Scherer, J., \& Sam, M. P. (2008). Public consultation and stadium developments: Coercion and the polarization of debate. Sociology of Sport Journal, 25, 443-461.

Spirou, C. (2010). Cultural policy and the dynamics of stadium development. Sport in Society, $13,1423-1437$.

Strauss, A. L., \& Corbin, J. (1990). Basics of qualitative research: Grounded theory procedures and techniques. Newbury Park, CA: Sage.

Trimble, M. (2011, December 20). Franklin County Commissioners approve arena deal. WOSU. Retrieved from http://beta.wosu.edu

Trumpbour, R. C. (2006). The new cathedrals: Politics and media in the history of stadium construction. Syracuse, NY: Syracuse University Press. 
Weiner, J. (2000). Stadium games: Fifty years of big league greed and bush league boondoggles. Minneapolis, MN: University of Minnesota Press.

Zimbalist, A. (2004). May the best team win: Baseball economics and public policy. Washington, DC: The Brookings Institution Press. 


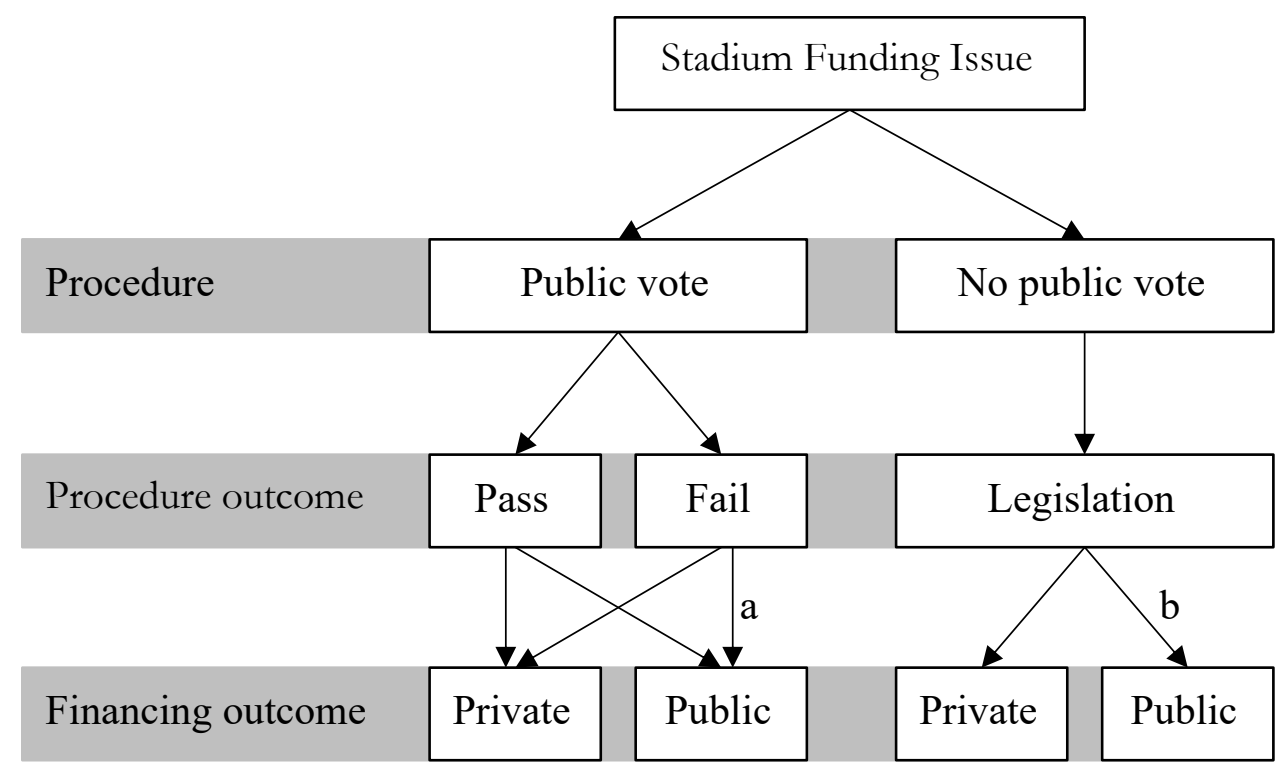

Figure 1. Possible sport facility financing outcomes with public interests, with attention drawn to the scenarios in which civic paternalism could be applicable. This model includes the procedures for making decisions, possible procedure outcomes, and possible financing outcomes. The relationships between (a) fail (procedure outcome) and public (financing outcome) and (b) legislation (procedure outcome) and public (financing outcome) reflect the potential presence of civic paternalism based on the decision to allocate public funds toward stadium projects without voter approval. 
Table 1.1: North American Professional Sport Facilities Receiving Public Funding Since 2005

\begin{tabular}{|c|c|c|c|c|c|c|c|}
\hline Team & League & Venue & $\begin{array}{c}\text { Date } \\
\text { opened }\end{array}$ & $\begin{array}{c}\text { Overall } \\
\text { cost }\end{array}$ & $\begin{array}{c}\text { Public } \\
\text { cost }\end{array}$ & $\begin{array}{l}\text { Public } \\
\text { percent }\end{array}$ & $\begin{array}{l}\text { Vote } \\
\text { held? }\end{array}$ \\
\hline Miami Marlins & MLB I & Marlins Ballpark & 2012 & $\$ 645$ & $\$ 490$ & $76 \%$ & no \\
\hline Minnesota Twins & MLB 1 & Target Field & 2010 & $\$ 555$ & $\$ 356$ & $64 \%$ & no \\
\hline New York Mets & MLB & Citi Field & 2009 & $\$ 830$ & $\$ 614$ & $74 \%$ & no \\
\hline New York Yankees & MLB & Yankee Stadium & 2009 & $\$ 2,308$ & $\$ 1,186$ & $51 \%$ & no \\
\hline Kansas City Royals & MLB $\mathrm{F}$ & Kaufmann Stadium & $2009 *$ & $\$ 250$ & $\$ 175$ & $70 \%$ & yes $^{\wedge}$ \\
\hline Washington Nationals & MLB I & Nationals Park & 2008 & $\$ 693$ & $\$ 693$ & $100 \%$ & no \\
\hline St. Louis Cardinals & MLB $\mathrm{F}$ & Busch Stadium & 2006 & $\$ 365$ & $\$ 45$ & $12 \%$ & no \\
\hline Houston Dynamo & MLS $\mathrm{F}$ & BBVA Compass Stadium & 2012 & $\$ 95$ & $\$ 35$ & $37 \%$ & no \\
\hline Sporting Kansas City & MLS I & Livestrong Sporting Park & 2011 & $\$ 160$ & $\$ 80$ & $50 \%$ & no \\
\hline Portland Timbers & MLS & Jeld-Wen Field & $2011 *$ & $\$ 36$ & $\$ 32$ & $89 \%$ & no \\
\hline Vancouver Whitecaps FC & MLS $\mathrm{F}$ & BC Place Stadium & $2011 *$ & $\$ 563$ & $\$ 563$ & $100 \%$ & no \\
\hline New York Red Bulls & MLS I & Red Bull Arena & 2010 & $\$ 200$ & $\$ 84$ & $42 \%$ & no \\
\hline Philadelphia Union & MLS I & PPL Park & 2010 & $\$ 120$ & $\$ 77$ & $64 \%$ & no \\
\hline Real Salt Lake & MLS F & Rio Tinto Stadium & 2008 & $\$ 110$ & $\$ 45$ & $41 \%$ & no \\
\hline Colorado Rapids & MLS I & Dick’s Sporting Goods Park & 2007 & $\$ 131$ & $\$ 66$ & $50 \%$ & yes $^{\wedge}$ \\
\hline Toronto FC & MLS I & BMO Field & 2007 & $\$ 63$ & $\$ 45$ & $71 \%$ & no \\
\hline Chicago Fire & MLS 1 & Toyota Park & 2006 & $\$ 98$ & $\$ 98$ & $100 \%$ & no \\
\hline FC Dallas & MLS I & FC Dallas Park & 2005 & $\$ 80$ & $\$ 80$ & $100 \%$ & no \\
\hline Orlando Magic & NBA & Amway Center & 2010 & $\$ 480$ & $\$ 430$ & $90 \%$ & no \\
\hline Brooklyn Nets & NBA & Barclays Center & 2012 & $\$ 772$ & $\$ 260$ & $34 \%$ & no \\
\hline Charlotte Hornets & NBA 1 & Time Warner Cable Arena & 2005 & $\$ 265$ & $\$ 265$ & $100 \%$ & yes $\dagger$ \\
\hline Minnesota Vikings & NFL 1 & New Minnesota Stadium & 2016 & $\$ 975$ & $\$ 498$ & $51 \%$ & no \\
\hline New Orleans Saints & NFL & Mercedes-Benz Superdome & $2011 *$ & $\$ 336$ & $\$ 321$ & $96 \%$ & no \\
\hline Kansas City Chiefs & NFL & Arrowhead Stadium & $2010^{*}$ & $\$ 375$ & $\$ 250$ & $67 \%$ & yes $^{\wedge}$ \\
\hline Dallas Cowboys & NFL & Cowboys Stadium & 2009 & $\$ 1,150$ & $\$ 325$ & $28 \%$ & yes $^{\wedge}$ \\
\hline Indianapolis Colts & NFL I & Lucas Oil Stadium & 2008 & $\$ 720$ & $\$ 620$ & $86 \%$ & no \\
\hline Arizona Cardinals & NFL I & University of Phoenix Stadium & 2006 & $\$ 455$ & $\$ 332$ & $73 \%$ & no \\
\hline Pittsburgh Penguins & NHL & CONSOL Energy Center & 2010 & $\$ 321$ & $\$ 244$ & $76 \%$ & no \\
\hline New Jersey Devils & NHL $\mathrm{I}$ & Prudential Center & 2008 & $\$ 375$ & $\$ 210$ & $56 \%$ & no \\
\hline
\end{tabular}

Note. Costs listed in US\$ millions or C\$ millions (respective to facility location). Figures rounded to nearest million; percentages rounded to nearest whole percent. For full reference list, please contact corresponding author.

$*$ renovated facility. ${ }^{\wedge}$ initiative/referendum passed. $\uparrow$ referendum failed. $\mathrm{MLB}=$ Major League Baseball. $\mathrm{MLS}=$ Major League Soccer. NBA = National Basketball Association. NFL $=$ National Football League. NHL $=$ National Hockey League. 